\title{
Face Recognition Untuk Akses Pegawai Bank Menggunakan Deep Learning Dengan Metode CNN.
}

\author{
Muhammad Arsal ${ }^{a}$, Bheta Agus Wardijono ${ }^{b}$, Dina Anggraini ${ }^{c}$ \\ ${ }^{a}$ Magister Manajemen Sistem Informasi, Universitas Gunadarma, Jl. Margonda Raya No. 100 Pondok Cina, Depok 16424, Indonesia \\ ${ }^{b}$ Teknik Informatika, Universitas Gunadarma, Jl. Margonda Raya No. 100 Pondok Cina, Depok 16424, Indonesia \\ ${ }^{c}$ Magister Manajemen Sistem Informasi, Universitas Gunadarma, Jl. Margonda Raya No. 100 Pondok Cina, Depok 16424, Indonesia
}

\section{INFORMASI ARTIKEL}

Sejarah Artikel:

Diterima Redaksi: 21 Februari 2020

Revisi Akhir: 07 Juni 2020

Diterbitkan Online: 09 Juni 2020

\section{KATA KUNCI}

\author{
Akses \\ Convolutional Neural Network \\ Deep Learning \\ Face Recognition
}

\section{KORESPONDENSI}

E-mail : muharsal15@gmail.com

\section{A B S T $\mathbf{R}$ A $\mathbf{C}$ T}

Perkembangan teknologi berkembang dengan sangat cepat, sehingga memberikan banyak manfaat khususnya dalam bidang Teknologi Informasi. Permintaan layanan dengan penggunaan teknologi semakin banyak dibutuhkan oleh perusahaan. Salah satu perusahaan yang membutuhkannya adalah perusahaan perbankan. Perkembangan teknologi memudahkan perusahaan untuk bisa menyelesaikan masalah, salah satunya masalah dalam sistem keamanan. Sistem kemanan dibutuhkan dalam setiap perusahaan dalam segala aspek. Sistem keamanan untuk pintu akses pegawai merupakan permintaan sebuah perusahaan bank yang dibuat dalam penelitian ini. Pada penelitian ini, dilakukan sistem keamanan pintu akses pegawai bank dengan menggunakan face recognition. Teknologi Face Recognition menggunakan pembahasan Deep Learning. Pembuatan aplikasi ini menggunakan algoritma Convolutional Neural Network (CNN). Bahasa pemrograman yang digunakan dalam pembuatan program ini yaitu python. Proses pembuatan aplikasi ini dengan tahapan pembuatan Face Recognition yaitu akuisisi gambar, preprocessing, ektraksi, klasifikasi, dan identifikasi data gambar. Penelitian ini berhasil menggunakan Face Recognition oleh 5 orang dataset wajah pegawai bank yang terdiri dari 70 data wajah pada masing-masing orang. Sehingga total data wajah yang digunakan 350 data wajah. Dataset tersebut dipisahkan menjadi 3 tahapan data yaitu data train, data validasi, dan data uji. Hasil dari pengujian ketiga dataset tersebut berhasil mengidentifikasi wajah yang ditangkap oleh kamera dengan persentase keakuratan 95\%. Program pada penelitian ini berhasil digunakan bank untuk pintu akses ruangan perkantoran oleh pegawai bank.

\section{PENDAHULUAN}

Teknologi berkembang dengan sangat pesat pada zaman ini, sehingga memberikan banyak manfaat di berbagai bidang, khususnya dalam Teknologi Informasi. Teknologi Informasi banyak juga digunakan untuk membantu manusia dalam menyelesaikan berbagai macam pekerjaan. Teknologi Informasi juga adalah sarana untuk meningkatkan kemampuan manusia dan instrument perubahan [1]. Salah satu teknologi Informasi yang sedang berkembang saat ini adalah face recognition. Face Recognition adalah metode sebuah teknologi dengan proses mengenali wajah yang diterapkan pada teknologi yang ada [2]. Teknologi tersebut seperti kamera, komputer, telepon pintar, dan lain sebagainya. Teknologi ini banyak hal yang dapat digunakan untuk membantu berbagai macam pekerjaan manusia. Setiap harinya manusia melakukan segala kegiatan dengan cara konvensional, seperti kunci pintu yang masih menggunakan kunci konvensional, dan absensi masih menggunakan fingerprint bahkan tabel excel. Teknologi Face Recognition dapat integrasikan teknologi otomatis dengan konvensional seperti absen menggunakan pemindai wajah dan akses untuk membuka pintu menggunakan pemindai wajah. 
Hal ini menarik untuk dirancang dan direalisasikan karena saat ini teknologi untuk keamanan suatu pintu masih menggunakan system keamanan konvensional. Keamanan konvensional terkadang memiliki beberapa kekurangan seperti membutuhkan kunci konvensional (fisik) dan kartu akses yang harus dibawa. Jika kunci - kunci konvensional tersebut mengalami kendala seperti patah kunci atau kartu tertinggal, maka orang tidak dapat membuka pintu. Pada beberapa tempat seperti mall dan perkantoran, pintu dengan membutuhkan sensor ataupun akses sudah banyak dijumpai. Terutama di perkantoran, setiap pengunjung harus memiliki kartu akses untuk dapat membuka pintu. Dalam penggunaannya kartu akses diberikan akses untuk membuka beberapa pintu tertentu. Setelah itu kartu akses biasanya diberikan kepada pengunjung yang intensitas kedatangannya sering atau pegawai perusahaan. Dengan menggunakan face recognition, pegawai tidak perlu menggunakan kartu akses karena wajah mereka sudah di daftarkan kedalam dataset perusahaan untuk diberikan akses pintu.Sebelum suatu sistem melakukan pengenalan wajah, maka sistem tersebut harus melakukan pendeteksian wajah untuk menentukan bahwa gambar wajah yang mampu diambil oleh kamera. Pendeteksian wajah ni digunakan karena terkadang gambar wajah yang diambil oleh kamera tercampur dengan objek lain disekitarnya yang tidak ingin di deteksi. Metode yang biasa digunakan untuk menemukan pola wajah pada suatu gambar adalah metode Haar Feature-Based Cascade Classifier. Metode ini sering digunakan karena dapat menangkap pola wajah dan mampu membuang daerah pada gambar yang tidak memiliki pola wajah [2].

Untuk merancang dan membuat Face Recognition ini digunakan Machine Learning dengan model supervised learning. Machine Learning adalah bagian dari ilmu kecerdasan buatan yang digunakan untuk mengganti atau menirukan perilaku manusaia untuk menyelesaikan masalah. Sedangkan supervised learning adalah teknik pembelajaran dalam Machine Learning yang membuat suatu fungsi dari data yang diberikan [3]. Teknologi Face Recognition ini dibutuhkan data - data berupa gambar dari wajah pegawai bank yang berfungsi sebagai kunci akses untuk membuka pintu akses bank.

Dalam proses Face Recognition ini juga digunakan algoritma Convolutional Neural Netwok (CNN). Pada dasarnya algorritma CNN adalah arsitektur jaringan syaraf tiruan yang lebih efektif untuk klasfikasi citra. Konsep utama CNN sendiri terdapat pada operasi konvolusi yang dimiliknya, dimana suatu citra akan diektrasi setiap fiturnya agar terbentuk beberapa pola yang akan lebih mudah untuk diklasifikasi [4]. Teknik ini dapat membuat fungsi pembelajaran gambar menjadi lebih efisien untuk diimplementasikan.

Perkembangan Machine Learning sekarang ini sudah dipermudah oleh banyaknya library dan Application Program Interface (API). Library untuk Machine Learning biasanya berbasis Bahasa pemrograman Python. Penggunaan library pada python menggunakan Tensorflow untuk mengekpresikan suatu permaslahan matematika pada Deep Learning. Deep learning merupakan salah satu bidang dari Machine Learning yang memanfaatkan jaringan syaraf tirutambahkan saran untuk implementasi permasalahan dengan dataset yag besar [5] Tensorflow memiliki fitur untuk melatih model menggunakan Graphics Processing Unit (GPU). Library lain yang dipakai Deep Learning yaitu Keras. Keras menggunakan beberapa fitur dari Tensorflow untuk membuat jaringan syaraf tiruan karena Keras sudah menyediakan beberapa model dasar CNN yang telah di optimasi untuk mempermudah Deep Learning.

Pada penelitian ini telah dilakukan kajian terhadap penelitian penelitian sebelumnya yang berhubungan dengan Face Recognition dan Convolutional Neural Network (CNN). Terdapat beberapa penelitian terkait yang telah dikaji, seperti penelitian pada jurnal Sepritahara dilakukan penelitian untuk Face Recognition dengan menggunakan metode Hidden Markov Model (HMM) [6]. Metode ini memiliki beberapa langkah yang dilakukan seperti pelabelan, codebook dan training database HMM dan pengenalan citra wajah. Pada proses pelabelan dilakukan pembuatan label untuk setiap gambar wajah. Setiap gambar wajah akan dikelompokan dalam satu label sesuai dengan nama yang sesuai dengan dataset. Pada langkah kedua yaitu codebook. Langkah ini melakukan pembuatan codebook pada label-label yang dibentuk. Langkah berikutnya adalaha membuat training database model HMM dari label dan codebook yang sudah terbentuk sebelumnya. Proses training ini menentukan hasil yang didapat berupa nama di label yang telah dibuat sesuai dengan codebook yang didapatkan. Langkah ini menghasilkan hasil keakuratan sebesar 84,28\% [6].

Pada jurnal Huang et al penelitian dengan judul Densley Connected Convolutional Network ini menggunakan metode part-stacked CNN [7]. Metode ini menggunakan dataset dan memasukkan setiap part pada sebuah gambar untuk dijadikan perbandingan. Proses ini memecah sebuah gambar dan mengambil setiap potongannya. Metode ini memiliki proses mengolah citra yang lebih cepat daripada metode lain sehingga metode ini baik digunakan secara real time. Kekurangan metode ini ialah keakuratannya. Hasil akurasi metode ini tidak lebih bak dari metode bilinear CNN yang tidak melakukan part attention pada citra. Arsitektur yang digunakan pada metode part-stacked CNN adalah arsitektur cafeNet. Akurasi yang didapatkan dengan metode ini sebear 76,63\% [7].

Pada jurnal Yang et al penelitian ini menggunakan algoritma Two Stage CNN [8]. Sebelum melakukan two stage CNN, program ini melakukan multi scale algoritma. Langkah ini bertujuan sebagai proses pengambilan gambar secara luas. Mendapatkan setiap gambar wajah dengan multi - scale menghasilkan tangkapan gambar beberapa wajah dalam satu kamera. Setelah proses multi scale didapatkan maka dilakukan langkah two stage CNN. Langkah ini berfungsi untuk memisahkan beberapa gambar yang ditangkap sesuai dengan tipikal. Setelah memisahkan gambar sesuai tipikalnya maka didapatkan klasifikasi gambar yang dapat diidentifikasi sesuai dengan dataset atau database yang tersimpan. Proses ini mendapatkan hasil akurasi sebesar 70\% [8].

Pada penelitian Parkhi diterapkan 3 model langkah arsitektur. Langkah yang pertama yaitu Rectified Linear Unit (ReLU) [9]. Model arsitektur ini menghilangkan vanishing gradient pada gambar untuk memisahkan gradient pada gambar agar lebih mudah diklasifikasikan. Langkah kedua yaitu Max Pooling Layer. Pada 
langkah ini layer kedua menangkap hasil layer pertama yang sudah melalui proses Rectified Linera Unit sehingga akan didapatkan detail gambar yang lebih baik. Langkah ketiga yaitu proses Fully Connected (FC). Pada proses ini semua layer digabungkan untuk mendapatkan hasil yang dapat di klasifikasikan sesuai dengan dataset yang tersimpan. Akurasi yang didapatkan sebesar 80\% [9]. Pada jurnal $\mathrm{Fu}$ et al penelitian dilakukan dengan menggunakan metoda Reccurent Attention CNN. Metode ini menggabungkan beberapa skala dari rancangan yang digunakan. Hasil yang didapat lebih akurat dibandingkan dengan hasil dari algoritma bilinear CNN. Persentase keakuratan yang didapat dari penggunaan Reccurent Attention CNN adalah 85,3\% [10].

Penelitian Face Recognition Untuk Akses Pintu Pegawai Bank Menggunakan Machine Learning dengan Metode Convolutional Neural Network (CNN) ini menggunakan model arsitektur VGG16. VGG16 adalah arsitektur CNN dengan input yang digunakan berupa RGB image berukuran $224 \times 224$ pixels. Convolutional layer yang digunakan dalam arsitektur ini ada 2 jenis, yaitu convolutional layer dengan ukuran filter $3 \times 3$ (conv3) dan ukuran filter $1 \times 1$ (conv1). Ukuran convolutional layer yang digunakan bermacam-macam, yaitu 64x64, 128x128, 256x256, dan 512x512. Model ini merupakan yang paling baik dalam localization dan classification. Metode CNN yang digunakan dalam aplikasi ini ialah bilinear CNN yang merupakan salah satu metode terbaik untuk saat ini sehingga masih dapat mendapatkan hasil akurasi yang lebih baik.

\section{METODE}

Tahapan yang dilakukan dalam penelitian ini, yaitu Analisa, perancangan atau design sistem, pengembangan atau coding, pengujian, dan implemntasi. Berikut adalah tahapan - tahapan yang dilakukan dalam penelitian ini :

\subsection{Tahap Analisa}

Tahap Analisa ini melakukan analisa dan pemantauan pada sistem atau aplikasi yang sedang berjalan, dan melakukan proses pengumpulan data

\subsubsection{Tahap Analisa Sistem Yang Berjalan}

Proses Analisa sistem yang sedang berjalan dengan melihat langsung sistem keamanan pada pintu akses perkantoran suatu bank. Pada Analisa sistem keamanan tersebut didapatkan pintu akses suatu bank masih menggunakan kartu akses sebagai alat untuk membuka pintu. Sistem keamanan tersebut tentu memerlukan sebuah kartu agar dapat membuka pintu, sehingga menimbulkan kekurangan dalam pengaplikasian pada penggunaan sehari - hari.

\subsubsection{Pengumpulan Data}

Pada proses Analisa dengan pengumpulan data untuk menguji aplikasi dilakukan berdasarkan kategori data.

- Data Train (Pelatihan )

- Data Validasi

- Data Test ( Uji )

\subsection{Tahap Design}

Tahap Design pada penelitian ini adalah tahapan yang melakukan perancangan sistem yang terdiri dari arsitektur program, algoritma, dan pembutan face recognition. Tahap pembuatan Face Recognition terdiri dari,

- akuisisi gambar,

- preprocessing,

- ekstraksi gambar,

- klasifikasi,

- identifikasi.

\subsection{Tahap Pengembangan}

Pada tahap Pengembangan merupakan tahapan pembuatan program dengan coding menggunakan algoritma Convolutional Neural Network (CNN). Program ini menggunakan framework tensorflow dan arsitektur model VGG16 untuk mengidentifikasi gambar menjadi lebih akurat. Proses coding melakukan beberapa tahap antara lain :

- Enrollment,

- Model,

- Training,

- Identify.

\subsection{Tahap Pengujian atau Testing}

Tahap Pengujian atau testing dilakukan dengan menjalankan aplikasi yang telah dibuat pada laptop atau computer dengan kamera. Mengidentifikasi wajah yang tertangkap oleh kamera sesuai dengan dataset yang telah disimpan. Tahapan ini akan menentukan bahwa aplikasi atau program berhasil dibuat.

\subsection{Tahap Implementasi}

Tahap Implementasi merupakan tahapan terakhir dimana program dilihat hasilnya dan dibahas. Setelah itu mendapatkan hasil dan bahasannya maka aplikasi dapat di implementasikan atau dijalankan dalam sistem keamanan pintu akses pegawai bank.

Gambar 1 merupakan detail dari tahapan yang dilakukan dalam penelitian ini. Garis berwarna biru muda untuk menunjukkan tahap Analisa yang berisi pengumpulan data beserta jenis data yang diambil. Garis berwarna pink menunjukkan tahap Design yang berisi perancangan sistem meliputi arsitektur, algoritma dan pembuatan face recognition. Garis berwarna ungu menunjukkan tahap Pengembangan yaitu proses Coding. Garis berwarna hijau menunjukkan tahap pengujian yang berisi testing program. Garis berwarna merah menunjukkan tahap Implementasi yaitu proses implementasi aplikasi ke pintu akses bank. 


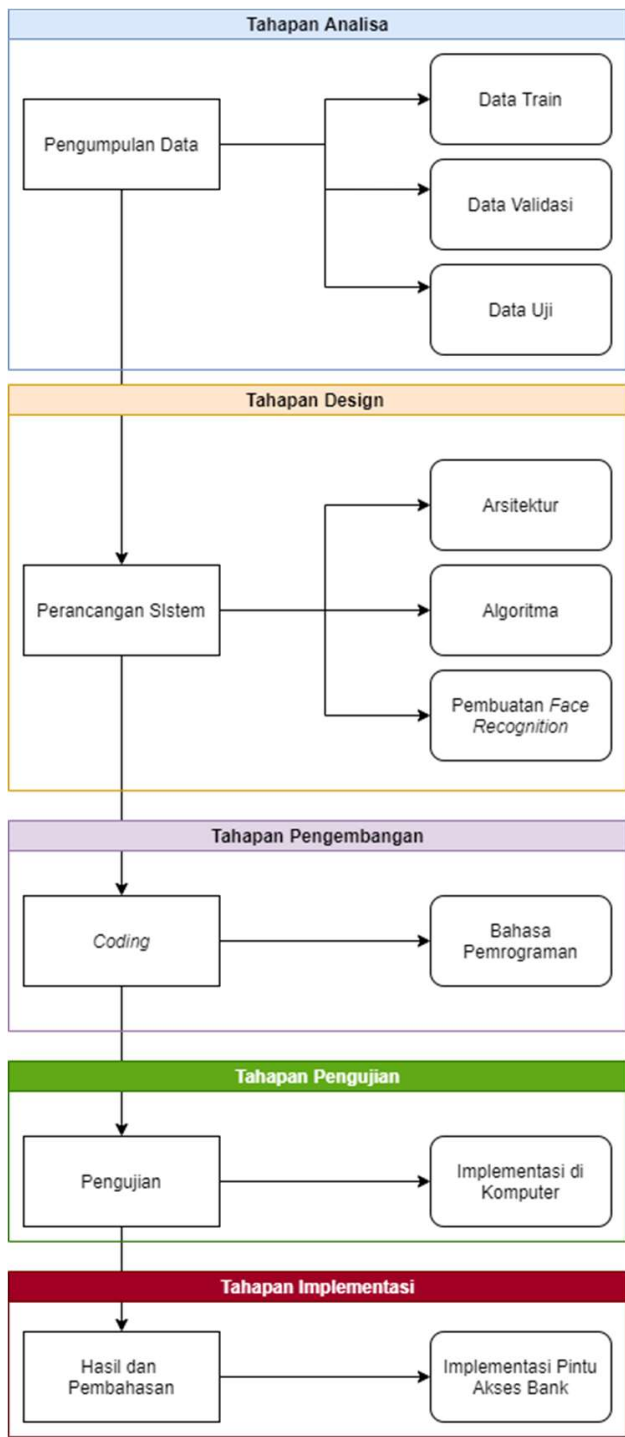

Gambar 1. Tahapan Penelitian

\section{HASIL DAN PEMBAHASAN}

\subsection{Pengumpulan Data}

Face Recognition membutuhkan beberapa data untuk melakukan proses pelatihan gambar. Data yang dibutuhkan untuk proses Face Recognition dibagi 3, yaitu data train (latihan), data tes, dan data evaluasi. Data train digunakan sebagai pelatihan program untuk menyimpan banyaknya data. Data tes adalah data yang digunakan sebagai pembanding dengan data train yang dipelajari. Data evaluasi adalah data yang digunakan untuk pembandingan dari data train dan data tes yang hasilnya akan dipakai sebagai trigger atau tolak ukur keakuratan gambar yang diambil dengan data yang disimpan.

Semakin banyak data yang digunakan maka akan lebih banyak program berlatih sehingga memiliki tingkat akurasi yang lebih baik. Data-data tersebut berupa gambar dari wajah pegawai bank yang diambil beberapa banyak. Data tersebut dikumpulkan dalam satu folder bernama dataset. Setiap dataset dibagi beberapa folder sesuai dengan nama dari pegawai. Jumlah pegawai yang diambil untuk sample sebanyak 5 orang dengan jumlah data 70 gambar.

\subsubsection{Data Train (Pelatihan)}

Pada data train diambil 45 gambar. Gambar tersebut diambil dari berbagai aspek, salah satunya dari aspek kategori arah wajah dan mimik wajah. Kategori arah wajah yaitu, menengok keatas, kebawah, ke kanan dan ke kiri. Aspek kategori gambar juga dari mimik wajah seperti, senyum, cemberut, melotot, menyipit, dan sebagainya. Dataset tersebut dipisahkan dengan wajah yang menggunakan kacamat dan tidak sehingga Face Recognition dapat menangkap dan validasikan wajah saat menggunakan kacamata dan tidak. Dataset train akan digunakan untuk melakukan pelatihan

\subsubsection{Data Validasi}

Data validasi adalah data yang digunakan sebagai data pembanding dengan data train. Fungsi data validasi yaitu sebagai pengakuratan model yang didapat dari data train (pelatihan). Data validasi terdiri dari 15 gambar yang berbeda dengan data train. Kumpulan gambar dari data validasi berbeda dengan data train. gambar pada data validasi terdiri dari ekspresi berbagai macam wajah dengan mimik dan arah wajah yang bermacam-macam menggunakan kacamata dan tidak menggunakan kacamata. Setelah data train dan data validasi melakukan pelatihan dan pengakuratan, maka akan disimpan dalam satu file yang menyimpan hasil pembelajaran dari kedua dataset tersebut. File dataset tersebut memiliki format h5 contohnya, bobot_train_validasi.h5. format h5 tersebut ialah format penyimpanan file yang termasuk dalam Hierarchical Data Format (HDF). File ini berisi data ilmiah dari array multidimensi. File tersebut biasanya digunakan dalam pengkodingan dengan bahasa pemrograman python

\subsubsection{Data Uji}

Data uji ialah data yang digunakan sebagai pembanding data dengan hasil pengujian data train dengan data validasi untuk menentukan hasil identifikasi. Data uji akan dibandingkan dengan data gabungan data train dan data validasi yang sudah di terbentuk menjadi bobot_train_validasi.h5. Banyak data yang disimpan dalam dataset uji ini sebanyak 10 data. Kumpulan gambar dari data uji berbeda dengan gambar dari data train dan data validasi seperti pada Gambar 3.4. Gambar pada dataset uji juga memiliki berbagai macam ekspresi dengan dan tanpa menggunakan aksesoris seperti kacamata. Setelah melakukan compare dengan data uji, maka hasil akan ditentukan.

\subsection{Tahap Pembuatan face recognition}

Langkah pembuatan Face Recognition terdiri dari beberapa proses. Proses dari saat pengambilan gambar yang dilakukan kamera sampai dengan identifikasi gambar.

\subsubsection{Akuisisi Gambar}

Citra atau gambar adalah representasi dua dimensi untuk bentuk fisik nyata tiga dimensi. Proses akuisisi citra Citra dalam perwujudannya dapat bermacam-macam, mulai dari gambar hitamputih pada sebuah foto atau gambar sampai pada gambar berwarna yang bergerak [11]. Proses Face Recognition dimulai dari tertangkapnya citra atau gambar oleh kamera yang disediakan. Penangkapan oleh kamera bisa mengambil beberapa gambar yang tertangkap, teknik tersebeut disebut multi Face Recognition [12]. Setelah tertangkap maka akan diambil sebuah gambar dan disimpan dalam dataset 


\subsubsection{Preprocessing}

Proses preprocessing ialah proses pengolahan data atau citra asli sebelum data atau citra tersebut diolah oleh algoritma Convolutional Neural Network (CNN) [13]. Proses Preprocessing memiliki beberapa cara yaitu merubah citra berwarna (RGB) menjadi greyscale, binerisasi gambar, cropping gambar [14]. Preprocessing memiliki beberapa tujuan, diantaranya:

1. Mengurangi hingga menghilangkan noise

2. Memperjelas fitur data atau citra (gambar)

3. Memperbesar atau memperkecil ukuran data atau citra

4. Mengkonversi data atau citra (gambar) asli menjadi sesuai yang dibutuhkan

\subsubsection{Ekstraksi Fitur}

Proses menentukan fitur - fitur dari gambar dengan diambilnya ciri - ciri yang unik untuk menentukan suatu citra. Proses Ektraksi fitur merupakan langkah pemisahan atau pemecahan suatu gambar berdasarkan ciri yang dimiliki gambar. Ekstraksi fitur menghasilkan nilai ciri yang beragam dari setiap individu. Keberagaman nilai ciri juga bergantung terhadap jumlah partisi. Semakin banyak jumlah partisi, maka nilai ciri yang diperoleh juga semakin banyak dan beragam [15]. Pada proses Face Recognition diperlukan wajah untuk diambil oleh kamera sehingga dapat diolah dan ditentukan sebagai identifikasi seseorang [16]. Umumnya wajah memiliki bentuk yang berbeda dengan organ - organ tubuh yang lain, sehingga ada tolak ukur beberapa organ yang dapat menentukan bahwa gambar atau citra yang diambil berupa wajah. Beberapa ciri wajah yaitu memiliki mata, hidung, dan mulut.Tujuan ekstraksi fitur diantaranya :

1. Memperkecil jumlah data atau citra

2. Memisahkan gambar sesuai dengan cirinya

3. Mengambil informasi yang paling penting dari data atau citra yang diolah

4. Mempermudah Face Recognition untuk mengidentifikasi suatu data atau citra

\subsubsection{Klasifikasi}

.Proses mengklasifikasikan gambar berguna sebagai pengelompokan gambar sesuai dengan beberapa gambar yang diambil dari data atau gambar yang telah di ekstraksi. Setelah data atau citra diekstraksi beberapa fitur, maka data akan dikelompokan menjadi beberapa kelompok supaya memudahkan untuk diketahui dalam proses identifikasi. Data yang sudah berhasil diekstraksi akan diketahui sebagai wajah atau bukan. Setelah itu data akan dikelompokan menjadi kelompok wajah orang tertentu dan wajah orang lainnya.

\subsubsection{Identifikasi}

Pada proses identifikasi, setiap data yang berupa gambar atau citra yang diakuisi atau ditangkap telah melakukan proses preprocessing, ekstraksi fitur dan klasifikasi, akan diidentifikasi berdasarkan dataset yang disimpan. Data yang telah dikelompokan dalam proses klasifikasi, akan dicocokan dengan dataset yang ada. Jika data klasifikasi cocok dan memiliki kemiripan yang banyak dengan yang ada di dataset, maka akan teridentifikasi sesuai dengan nama data yang ada dalam dataset.

\subsection{Tahap Pembuatan Coding}

Tahap pembuatan coding adalah proses pembuatan program dengan coding sesuai dengan bahasa pemrograman yang digunakan serta algoritma yang digunakan dalam pemrograman. Penelitian ini membuat program dengan menggunakan aplikasi atau software pycharm. Pycharm sebuah aplikasi IDE untuk melakukan pemrograman khusus bahasa pemrograman python. Algoritma yang digunakan $\mathrm{CNN}$ dengan dataset sesuai yang dirancang dan direncanakan

\subsubsection{Enrollment}

Kelas ini merupakan kelas yang berfungsi untuk mengambil beberapa citra yang tertangkap. Proses ini merupakan proses awal dalam pengkodingan dimana citra diambil melalui kamera untuk disimpan menjadi dataset

\subsubsection{Model}

Pada kelas ini proses pembuatan dan mempelajari model dilakukan. Program ini menggunakan framework komputasi Machine Learning yaitu, tensorflow. Tensorflow merupakan sebuah framework Machine Learning milik Google yang memiliki tools dan model untuk membantu proses jaringan saraf tiruan atau Convolutional Neural Network (cnn). Model VGG16 digunakan dalam pengkodingan model ini. VGG16 adalah suatu model dalam Convolutional Neural Network (CNN) untuk mengidentifikasi gambar dengan skala lebih besar. Tujuan penggunaan model VGG16 untuk mengidentifikasi gambar lebih akurat.

\subsubsection{Training}

Training merupakan proses pelatihan data dalam suatu dataset dengan dataset yang lain. Setiap gambar yang sudah dipisahkan dalam dataset yang berbeda akan dicocokan kembali dan dibuat satu kelompok data yang terbungkus dalam suatu file gabungan. Penelitian ini menggunakan data train dan data validasi saat melakukan proses training.

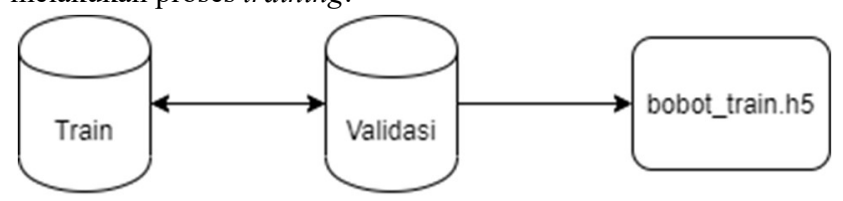

Gambar 2. Proses Training Dataset

Gambar 3 memperlihatkan bagan tahapan proses training. Dataset train akan dilatih dan dicocokan kembali dengan data validasi yang isinya berbeda dengan dataset train, setelah itu akan dikelompokan dalam satu file berformat .h5 dengan nama bobot_train.h5. Data dalam file bobot_train.h5 akan digunakan oleh proses selanjutnya untuk mengidentifikasi citra atau gambar yang diambil.

\subsubsection{Identify}

Tahap Identify merupakan tahap utama yang menjalankan fungsi fungsi proses identifikasi wajah. Proses identifikasi ini terdiri dari beberapa fungsi yang mengatur data, logika, dan tampilan yang akan dikeluarkan.

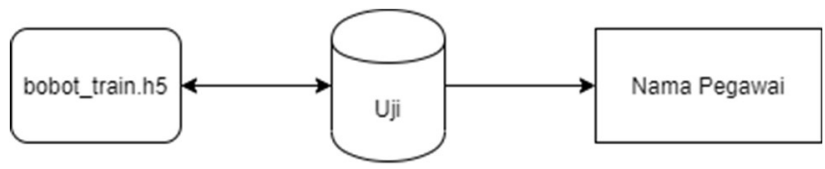

Gambar 3. Proses Identify 
Gambar 3 merupakan bagan proses pencocokan data uji dengan data bobot_train.h5. Proses pertama yaitu memanggil dataset yang akan digunakan, yaitu data bobot_train.h5 dengan dataset uji atau tes dari direktori penyimpanan file tersebut. Jika wajah yang tertangkap kamera cocok dengan data yang tersimpan di dataset, maka akan menampilkan nama wajah sesuai nama yang tersimpan di dataset. Jika wajah yang diambil tidak sama atau tidak cocok dengan yang ada di dalam dataset, maka label dalam frame akan menunjukan kata "UNKNOWN".

\subsection{Tahap Pengujian}

Setelah melalui perancangan dan pengkodingan program, maka program akan diuji coba. Dalam penelitian ini program akan diujicoba dengan menjalankan beberapa source program yang menggunakan bahasa pemrograman python. Setelah itu aplikasi akan mengaktifkan kamera yang sudah dipasang di device Raspberry Pi 4 dan menangkap wajah manusia yang tertangkap kamera. Dalam pengambilan wajah tersebut maka akan tampak sebuah kotak atau frame dengan label nama yang diberikan. Frame tersebut akan mendeteksi wajah yang tertangkap kamera.
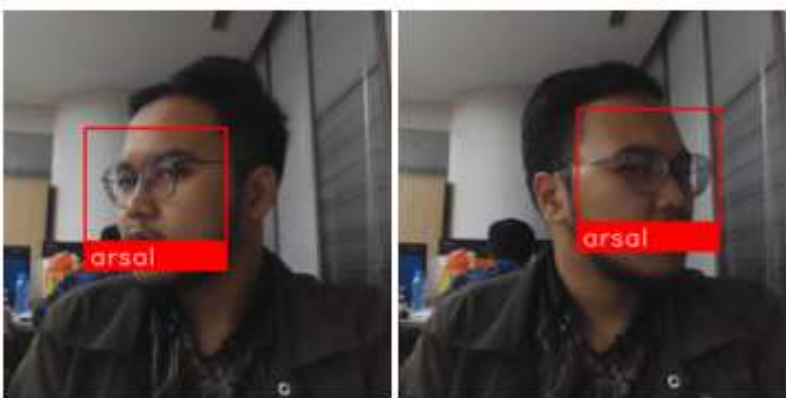

Gambar 4. Pengujian Identify Wajah Berhasil

Pada Gambar 4 merupakan tampilan dari proses Face Recognition yang berhasil mengidentifikasi wajah seseorang sesuai dengan data yang tersimpan dalam dataset. Frame merah akan menunjukan nama yang diambil dari nama dataset yang tersimpan.
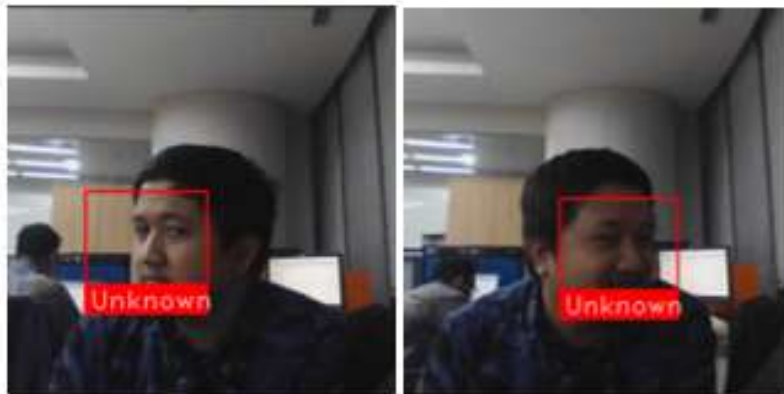

Gambar 5. Pengujian Identify Wajah Gagal

Pada Gambar 5 menunjukkan hasil Face Recognition dari identifikasi wajah yang gagal ditampilkan Namanya atau bertuliskan unknown. Hal ini terjadi dikarenakan wajah yang berhasil ditangkap oleh kamera, tidak dapat ditemukan dan dicocokan dengan dataset yang tersimpan, sehingga program akan menampilkan label pada frame merah tersebut dengan kata unknown atau tidak dikenal.

\subsection{Tahap Implementasi dan Hasil}

Setelah program berhasil dibuat, maka program akan diimplementasikan dengan kebutuhan user sebagai akses untuk pintu pegawai bank. Berikut ialah foto - foto penggunaan Face Recognition yang sudah diimplementasikan pada pintu akses suatu bank :

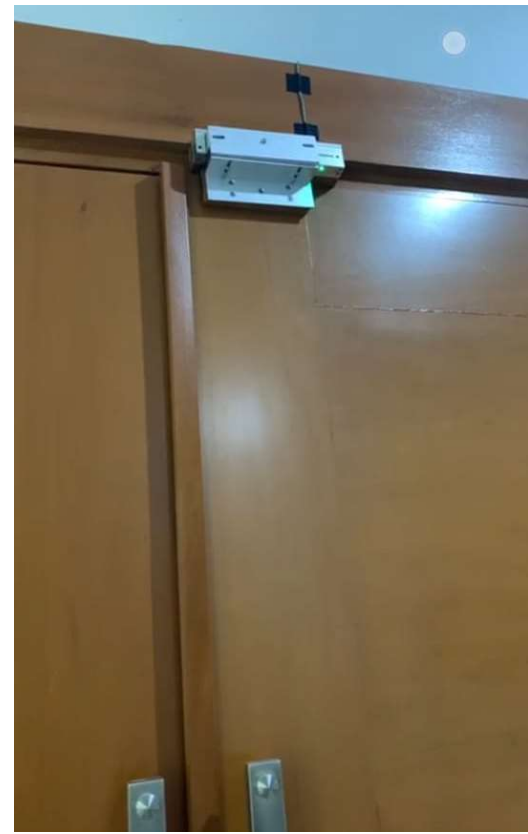

Gambar 6. Pintu Masuk Magnetic

Gambar 6 merupakan pintu akses perkantoran bank dengan dipasangkan sistem penguncian magnet. Penguncian magnet ini akan mengikuti perintah dari mesin operator Face Recognition melalui sinyal yang ditangkap

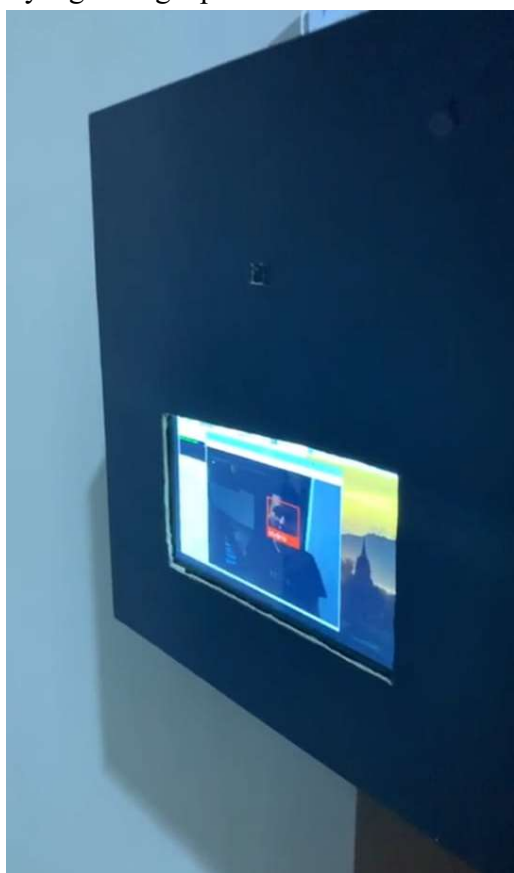

Gambar 7. Device Kamera dan Layar

Gambar 7 adalah device operator yang memiliki kamera, layar tablet dan mesin Raspberry didalamnya. Device ini bertugas untuk 
mengambil wajah pegawai bank dan melakukan proses identifikasi wajah untuk membuka akses pintu bank.

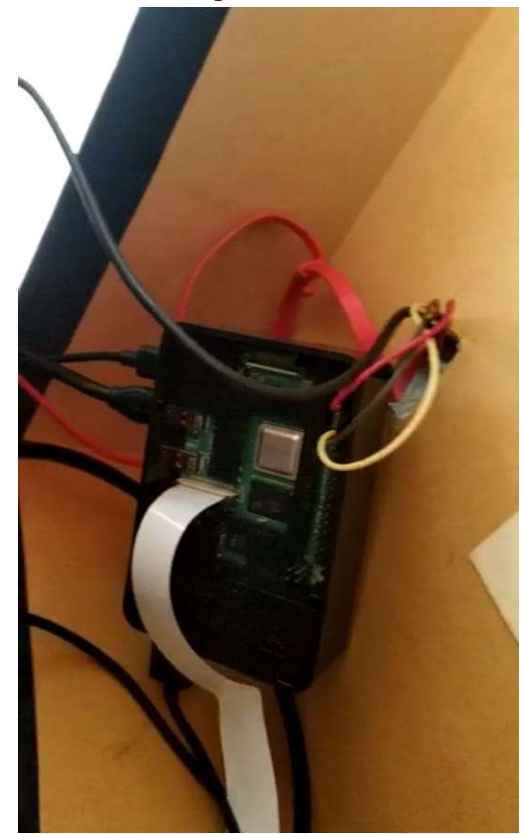

Gambar 8. Mesin Menggunakan Raspberry Pi 4

Gambar 8 merupakan mesin yang menggunakan raspberry Pi 4 sebagai prosesor pemrograman untuk menjalankan program face recognition. Mesin ini terintegrasi dengan kamera untuk mengambil gambar, layar sebagai tampilan wajah yang tertangkap, dan magnetic door sebagai pembuka akses pintu bank. Mesin ini menjalankan program dan mengirim perintah dengan bantuan sinyal kepada magnetic door.

Tabel 1. Hasil Uji Coba Data Test

\begin{tabular}{lll}
\hline $\begin{array}{l}\text { Data } \\
\text { Training (bobot) }\end{array}$ & Data Uji & \multicolumn{1}{c}{$\begin{array}{c}\text { Hasil Akurat } \\
\text { (berhasil/total) }\end{array}$} \\
\hline Bobot_train.h5 & Arsal & $10 / 10$ \\
\cline { 2 - 3 } (Hasil Training & Indra & $7 / 10$ \\
\cline { 2 - 3 } dari Data Train & Dian & $9 / 10$ \\
\cline { 2 - 3 } dengan & Iqbal & $10 / 10$ \\
\cline { 2 - 3 } Data Validasi) & Miki & $10 / 10$ \\
\cline { 2 - 3 } & Total (\%) & $46 / 10 \times 100=$ \\
& & $92 \%$ \\
\hline
\end{tabular}

Tabel 1 menunjukkan data hasil dari uji coba data uji dengan data bobo training. Data uji yang dimasukkan sebanyak 5 daftar dataset pegawai bank dengan masing-masing dataset berisi 10 data wajah. Dataset yang memiliki persentase hasil akurasi maksimal adalah dataset Arsal, Iqbal, dan Miki dengan memiliki hasil gambar akurat sebanyak 10 dari 10 gambar. Terdapat 2 dataset yang memilik

$$
\text { Persentase Keberhasilan }=\frac{\text { Data Berhasil }}{\text { Jumlah Data }} \times 100 \% \text {, }
$$

Persentase Kegagalan $=\frac{\text { Data Gagal }}{\text { Jumlah Data }} \times 100 \%$, maka

$$
\text { Persentase }=\frac{4}{50} \times 100 \%,=8 \%
$$

peresentase tidak sampai maksimal yaitu, dataset Indra dengan hasil gambar akurat sebanyak 7 dari 10 gambar dan dataset Dian dengan hasil gambar akurat sebanyak 9 dari 10 gambar. Kedua dataset tersebut jika dicoba dalam aplikasi akan memunculkan frame merah dengan menulikan kata unknown karena tidak dapat menentukan dengan akurat wajah yang ditangkap kamera. Maka total gambar yang berhasil diidentifikasi sebanyak 46 gambar dan 4 gambar gagal. Output dari hasil perhitungan keakuratan dilampirkan di bawah.

Penentuan hasil akurasi yaitu berdasarkan tingkat kecocokan dari data uji terhadap data training yang telah disimpan dalam bobot_train.h5. Data dalam Table 4.1 mendapatkan rata - rata akurasi dengan menjumlahkan total hasil data yang berhasil dibagi dengan jumlah dataset yang diuji.

Penelitian ini memiliki persentase tingkat akurasi sebesar 92\%, didapat dari jumlah data yang berhasil dibagi dengan jumlah data yang diuji. Tingkat kegagalan dalam penelitian ini sebesar $8 \%$, didapat dari jumlah data yang gagal dibagi dengan jumlah data yang diuji.

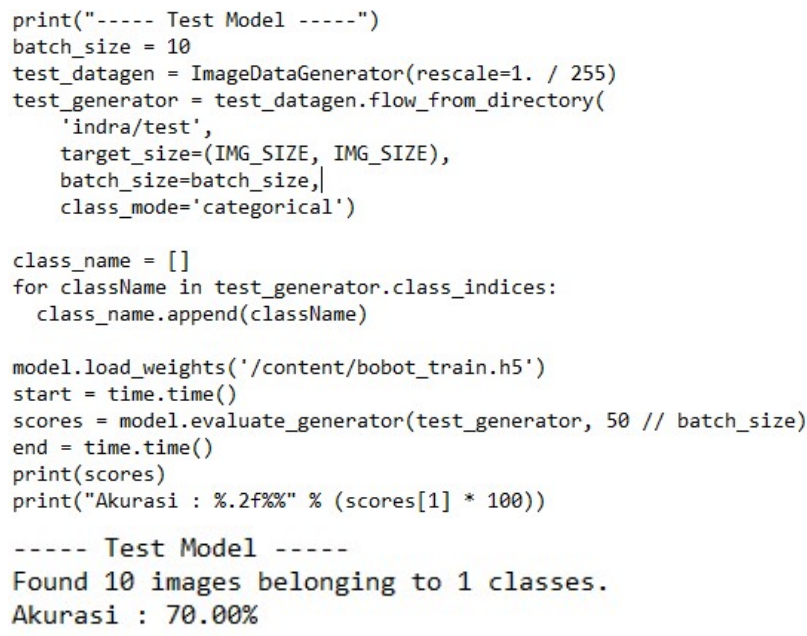

Pada Listing program atau source code diatas merupakan proses coding pengecekan dataset uji dengan data bobot training. Dataset yang dimasukkan dalam pengecekan akurasi ialah dataset Indra. Setelah melakukan proses pengecekan terhadap dataset uji Indra didapatkan penyebab tidak maksimalnya hasil akurasi data uji tersebut.

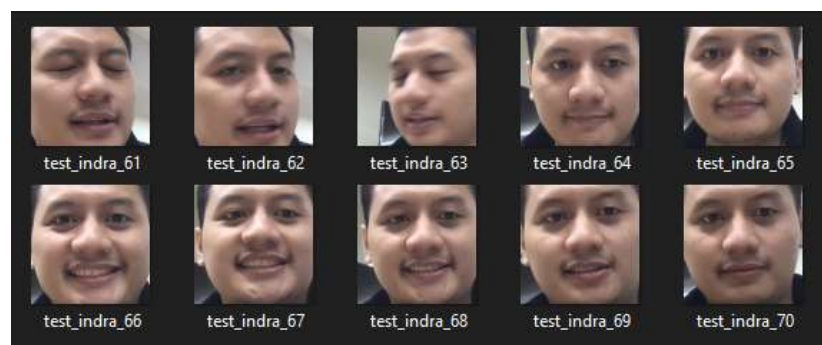

Gambar 9. Dataset Indra Lama 
Gambar 9 berikut yaitu isi dataset test Indra. Terdapat 10 data wajah yang akan di cocokan dengan data training bobot_train.h5. Dataset train ini memiliki hasil gambar yang akurat sebanyak 7 dari 10 gambar. Penyebab dari hasil akurasi tersebut teranalisa dari terdapatnya 3 gambar wajah yang kurang teridentifikasi sebagai wajah indra dalam data training. 3 gambar tersebut yaitu test_indra_61 sampai test_indra_63 yang memiliki kekurangan dalam hal blur gambar dan identifikasi mata. Analisa penulis yaitu 3 gambar tersebut tidak berhasil terkestraksi dengan baik dan mendapat masalah dalam identifikasi gambar wajah pegawai.

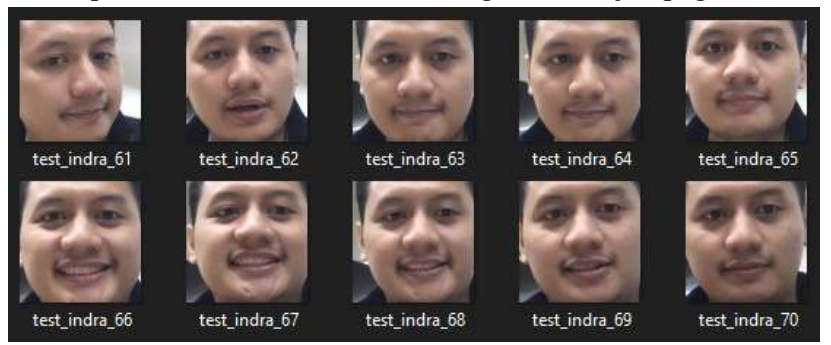

Gambar 10. Dataset Indra Baru

Pada Gambar 10 penulis mencoba mengganti 3 gambar dalam dataset Indra dengan gambar baru yang memilik kualitas lebih baik dalam hal blur dan tangkapan ketiga aspek identitas wajah yaitu mata, mulut, dan hidung. Setelah itu dilakukan kembali tes akurasi data uji dengan data training. Hasil tes akurasi tersebut terdapat pada log output dibawah ini dengan memiliki akurasi sebesar $100 \%$.
-...- Test Model -....

Found 10 images belonging to 1 classes. Akurasi : $100.00 \%$

Maka didapatkan kesimpulan bahwa hasil akurasi bergantung dengan data yang diuji. Hasil akurasi juga bisa berubah sesuai dengan jumlah data yang diuji, semakin banyak data yang diuji maka tingkat keakurasiannya akan lebih baik

Setelah didapatkan hasil penelitian ini, maka dapat dibandingkan dengan penelitian Parkhi et al dengan judul "Deep Face Recognition". Penelitian ini menggunakan metode CNN dengan 3 model arsitektur yaitu Rectified Linear Unit (ReLU), Max Pooling Layer, dan Fully Connected (FC).

Pada Gambar 10 didapatkan proses yang dilakukan dengan model arsitektur VGG16. Terdapat hasil penggabungan Langkah dari beberapa model arsitektur yaitu Rectified Linear Unit (ReLU), Max Pooling Layer, Fully Connected (FC), dan softmax. Setelah melakukan Fully Connected (FC) atau penggabungan semua layer yang telah melakukan proses $\mathrm{ReLu}$ dan Max Pooling Layer sehingga dapat mengidentifikasi gambar, maka dilakukan lagi model arsitektur softmax yaitu proses algoritma matematika yang melakukan pengklasifikasian object yang telah di gabungkan pada proses Fully Connected (FC) sehingga identifikasi objek lebih akurat. Pada penelitian ini proses identifikasi wajah dengan menggunakan model arsitektur VGG16 mendapatkan hasil yang lebih akurat daripada proses yang tidak menggunakannya.

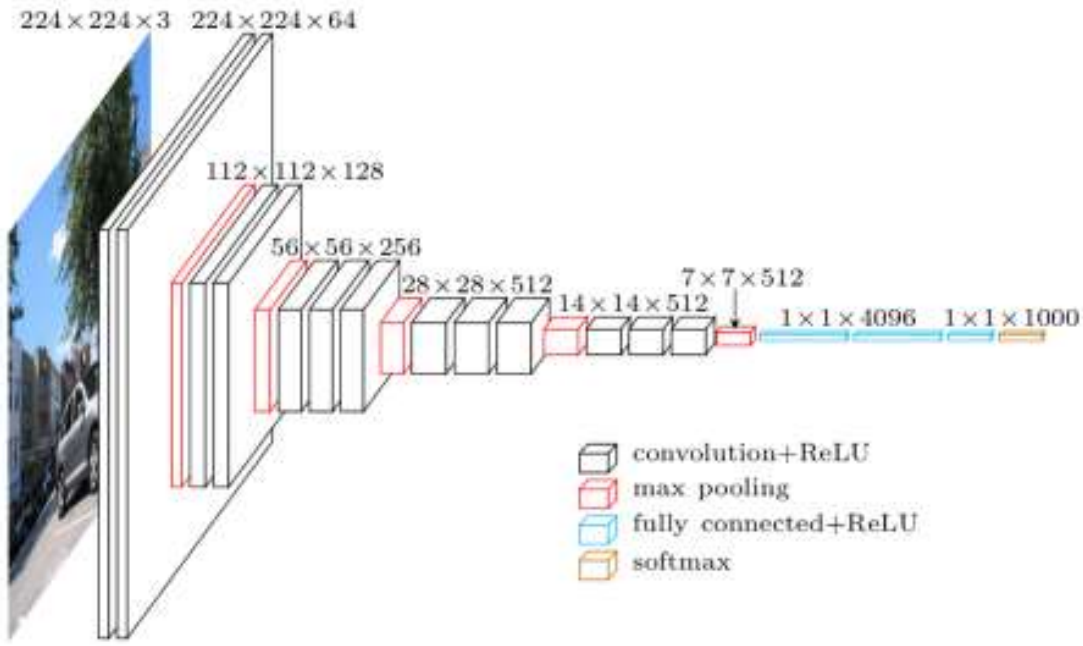

Architecture of VGG16

Gambar 11. Arsitektur VGG16

\section{KESIMPULAN}

Berdasarkan hasil penelitian yang telah melakukan perancangan dan perencanaan pembuatan program Face Recognition serta melalui pengujian yang telah dilakukan maka dapat diambil kesimpulan antara lain, Teknologi Face Recognition untuk akses pegawai bank dapat dilakukan menggunakan Convolutional Neural Network (cnn). Proses pembuatan aplikasi ini dengan tahapan pembuatan Face Recognition yaitu akuisisi gambar, preprocessing, ektraksi, klasifikasi, dan identifikasi data gambar.
Tahapan tersebut dibuat dengan bahasa pemrograman python. Penelitian ini berhasil menggunakan Face Recognition oleh 5 orang dataset wajah pegawai bank yang terdiri dari 70 data wajah pada masing-masing orang. Dataset tersebut dipisahkan menjadi 3 tahapan data yaitu data train, data validasi, dan data uji. Hasil dari pengujian ketiga dataset tersebut berhasil mengidentifikasi wajah yang ditangkap oleh kamera dengan persentase keakuratan 95\%. Program pada penelitian ini berhasil digunakan oleh sebuah bank untuk pintu akses ruangan perkantoran oleh pegawai bank. Pada penelitian selanjutnya program Face Recognition dalam penelitian 
ini dapat dijadikan acuan dan digunakan dalam sistem kemanan yang lebih besar serta luang lingkup yang lebih luas dalam perkembangan dunia teknologi.

\section{DAFTAR PUSTAKA}

[1] I. M. M. Yusa, Sinergi Sains, Teknologi Dan Seni: Dalam Proses Berkarya Kreatif Di Dunia Teknologi Informasi. STIMIK STIKOM INDONESIA ISBN:978-602-70665-0-2 [Maret 31, 2016].

[2] W. Taringan, "Pengenalan Wajah Dengan Menggunakan Metode Discriminateive Local Difference Patterns," Undergraduate thesis, Universitas Kristen Maranata, Bandung, 2017.

[3] Nurhayati, Busman, Rayi P.I. (2019, June) Pengembangan Algoritma Unsupervised Learning Technique pada Big Data Analysis Di Media Sosial Sebagai Media Promosi Online Bagi Masyarakat. JURNAL TEKNIK INFORMATIKA, [S.1.], v. 12, n. 1, p. 79-96, Available at: http://journal.uinjkt.ac.id/index.php/ti/article/view/11342

[Feb 15, 2020].

[4] X. Luo, R. Shen, J. Hu, L. Hu, Q. Guan. “A Deep Convolution Neural Network Model for Vehicle Recognition and Face Recognition," Procedia Computer Science. 107. 715-720. 10.1016/j.procs.2017.03.153. [December, 2017]

[5] Danukusumo, K. P., Pranowo, \& Maslim, M. "Indonesia ancient temple classification using Convolutional Neural Network," In 2017 International Conference on Control, Electronics, Renewable Energy and Communications (ICCREC) (pp. 50-54). IEEE. https://doi.org/10.1109/ICCEREC.2017.822670. [September, 2017].

[6] Sepritahara, "Sistem Pengenalan Wajah (Face recognition) Menggunakan Metode Hidden Markov Model (HMM)," Undergraduate thesis, Universitas Indonesia, Depok, 2016.

[7] S. Huang, Z. Xu, D. Tao, \& Y. Zhang, "Part-Stacked CNN for Fine-Grained Visual Categorization," Proceedings of the IEEE Conference on Computer Vision and Pattern Recognition, pp. 1173-1182. [June, 2016].

[8] S. Yang, P. Luo, C. C. Loy and X. Tang, "WIDER FACE: A Face Detection Benchmark," 2016 IEEE Conference on Computer Vision and Pattern Recognition (CVPR), Las Vegas, NV, 2016, pp. 5525-5533. [June, 2016].

[9] O. M. Parkhi, A. Vedaldi, A. Zisserman. "Deep Face Recognition," In Xianghua Xie, Mark W. Jones, and Gary K. L. Tam, editors, Proceedings of the British Machine Vision Conference (BMVC), pages 41.1-41.12. BMVA Press. [September 2015].

[10] J. Fu, H. Zheng and T. Mei, "Look Closer to See Better: Recurrent Attention Convolutional Neural Network for Fine-
Grained Image Recognition," 2017 IEEE Conference on Computer Vision and Pattern Recognition (CVPR), Honolulu, HI, 2017, pp. 4476-4484. [Mei, 2017].

[11] J. Utama, "Akuisisi Citra Digital Menggunakan Pemrograman Matlab." Undergraduate thesis, Universitas Komputer Indonesia, Bandung, 2018.

[12] O.N Akbar, I. I. Tritoasmoro, R. D. Atmaja, "Multi Face Recognition Menggunakan Complete Fuzzy Fisher Linear Discriminant," Undergraduate thesis, Telkom Univeristy, Bandung, 2015 .

[13] Y. Nabuasa, "Pengolahan Citra Dicangital Perbandingan Metode Histogram Equalization dan Spesification pada citra abu - abu," Jurnal Komputer Dan Informatika, vol. 7(1), pp. 87-95. https://doi.org/10.35508/jicon.v7i1.889 [Maret, 2019].

[14] C. N. Santi. "Mengubah Citra Berwarna Menjadi Gray-Scale dan Citra Biner", dinamik, vol. 16, no. 1. [Jan, 2011].

[15] M.S. Ramadhan, Ledya N., Susatio E. "Sistem Pengenalan Individu Berbasis Citra Wajah 3D dengan Jaringan Syaraf Tiruan," Techné : Jurnal Ilmiah Elektroteknika. Vol. 18. pp. 1-14. 10.31358/techne.v18i01.180. [April, 2019].

[16] A. Yudhana, Sunardi, S. Saifullah. "Perbandingan Segmentasi Pada Citra Asli dan Citra Kompresi Wavelet Untuk Identifikasi Telur," ILKOM Jurnal Ilmiah, vol. 8, no. 3, 2016, pp. 190-196, doi:10.33096/ilkom.v8i3.75.190-196 [December, 2016].

\section{BIODATA PENULIS}

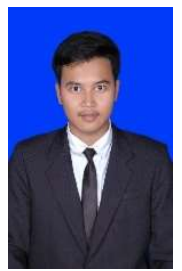

Muhamad Arsal APS

Lahir di Bandung, 15 Juli 1996. Pendidikan sarjana didapatkan dari Universitas Gunadarma pada Program Studi Teknik Informatika. Saat ini berkarir sebagai staf Application Developer Associate di PT. Mitra Integrasi Informatika.

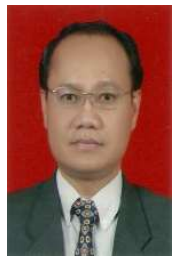

Bheta Agus Wardijono

Dosen di Universitas Gunadarma dan STMIK Jakarta STI\&K. Riwayat pendidikan: S1 dari Universitas Indonesia, S2 dari Universitas Trisakti dan S3 dari Teknologi Informasi Universitas Gunadarma.

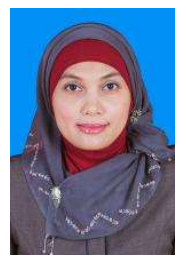

Dina Anggraini

Terlahir di Jakarta, 13 Agustus 1977, lulusan Doktoral Teknologi Informasi Universitas Gunadarma tahun 2018, merupakan peneliti di bidang Natural Language Processing, khususnya Text Mining. 